\title{
Pengembangan Buku Digital Matematika Saintifik pada Materi Persamaan Kuadrat
}

\author{
Nur Islah Asyhar, a), Asdar ${ }^{1, \text { b) }}$, dan Nurwati Djam'an ${ }^{1, c)}$ \\ ${ }^{1}$ Jurusan Matematika, Fakultas MIPA, Universitas Negeri Makassar \\ a) nur.islahasy@gmail.com \\ b)asdar_ahmad@unm.ac.id \\ c)nurwati_djaman@yahoo.co.id
}

\begin{abstract}
Abstrak. Penelitian pengembangan ini bertujuan mengembangkan buku digital matematika saintifik untuk materi persamaan kuadrat yang valid dan praktis. Penelitian ini menggunakan model pengembangan ADDIE yang meliputi 5 tahapan yaitu analysis, design, development, implementation, dan evaluation. Instrumen penelitian yang digunakan berupa lembar penilaian media oleh ahli media dan ahli materi untuk mengukur kevalidan serta angket respon siswa dan guru untuk mengukur kepraktisan buku digital matematika. Responden uji coba produk adalah 10 siswa kelas 8 . Hasil penelitian menunjukkan bahwa produk memenuhi kriteria kevalidan berdasarkan penilaian oleh ahli materi dan ahli media. Produk memenuhi kriteria kepraktisan berdasarkan respon siswa yang dikategorikan kuat dan respon guru yang dikategorikan sangat kuat.
\end{abstract}

Kata Kunci: pengembangan, buku digital matematika, pendekatan saintifik, ADDIE

\begin{abstract}
This development research aims to develop valid and practical a digital mathematics book scientific on the topic of quadratic equations. This research using the ADDIE development model, which includes 5 stages: analysis, design, development, implementation, and evaluation. The research instrument used is a form of media assessment sheets by media expert and material expert to measure the validity and students and teacher response questionnaires to measure the practicality of a digital mathematics book. Respondents for the product trial are 10 students of class VIII,1. The results showed that the product satisfies validity criteria based on the assessment by material expert and media expert. The product satisfies practicality criteria based on students response are categorized as strong and teacher response is categorized as very strong.
\end{abstract}

Keywords: development, digital mathematics book, scientific approach, ADDIE

\section{PENDAHULUAN}

Dalam kegiatan pembelajaran tidak terlepas dari komponen-komponen yang saling berkaitan didalamnya. Salah satu komponennya adalah bahan ajar. Bahan ajar dapat diartikan bahan atau materi pelajaran yang disusun lengkap dan sistematis berdasarkan prinsip-prinsip pembelajaran yang digunakan guru dan siswa dalam proses pembelajaran (Sungkono, 2009). Bahan ajar merupakan bahan atau materi pelajaran yang disusun sistematis baik tertulis maupun tidak tertulis yang digunakan oleh guru sehingga siswa mencapai standar kompetensi yang telah ditentukan (Raharjo \& I'anah, 2014). Berbagai macam bentuk bahan ajar salah satunya adalah buku digital.

Buku digital adalah publikasi berupa teks dan gambar dalam bentuk digital yang diterbitkan dan dapat dibaca di komputer atau alat digital lainnya (Andina, 2011). Buku digital merupakan kumpulan informasi dalam bentuk buku yang berisi teks, gambar, audio dan video yang dimuat secara digital sehingga dapat diakses menggunakan perangkat elektronik termasuk mobile (smart-phone dan tablet) (Prasetya, 2015; Ruddamayanti, 2019). 
Bentuk buku digital terbagi menjadi 2 yaitu Buku Elektronik dan buku audio. Buku elektronik (E-book) memiliki berbagai format seperti portable document format ( $p d f)$, hypertext markup $(\mathrm{htm})$ dan aplikasi. Format tersebut dapat dibuka dengan program Acrobat Reader, browsing atau internet eksplorer secara offline, dan aplikasi. Buku audio merupakan buku dalam bentuk suara yang diperkenalkan oleh Apple melalui iTunes $U$ yang menyediakan lebih dari 35000 video dari berbagai universitas di dunia (Andina, 2011).

Buku digital memungkinkan siswa untuk mempelajari materi sesuai kemampuan dan minat mereka, menawarkan berbagai fungsi interaktif, buku referensi, buku kerja, kamus, dan konten multimedia seperti video, animasi, dan virtual reality (Byun, Choi, \& Song, 2006; Kim \& Jung, 2010). Penggunaan bahan ajar berbasis digital book memiliki efektivitas yang lebih tinggi daripada bahan ajar cetak dalam meningkatkan hasil belajar siswa pada mata pelajaran matematika materi logika matematika di kelas X SMKN 2 Garut (Zaini, Darmawan, \& Hernawan, 2019)

Salah satu buku digital yang telah banyak digunakan sekolah-sekolah di Indonesia adalah Buku Sekolah Elektronik (BSE). BSE merupakan buku digital yang telah diuji kelayakan pakainya oleh Badan Standar Nasional Pendidikan dan telah ditetapkan sebagai buku teks pelajaran yang memenuhi syarat kelayakan untuk digunakan dalam pembelajaran (Andina, 2011).

Namun, BSE yang tersebar tersebut masih kurang menarik karena masih dalam bentuk buku konvensional yang diubah ke dalam bentuk e-book. Sebaiknya BSE mampu menampilkan simulasi-simulasi yang interaktif dengan perpaduan audio, video, animasi dan gambar. BSE yang tersebar saat ini masih banyak yang belum sesuai dengan kurikulum 2013 yaitu menggunakan pendekatan saintifik.

Terdapat beberapa penelitian yang relevan mengenai buku digital. Tambunan dan Sundari (2020) mengembangkan buku digital pada materi persamaan garis singgung lingkaran. Hasil penelitian menyatakan bahwa buku digital dinyatakan valid digunakan berdasarkan penilaian para ahli. Dengan demikian, buku digital yang dihasilkan interaktif, tampilan menarik, mudah digunakan, mudah diakses, dan mudah dipahami.

Marselina dan Muhtadi (2019) mengembangkan buku digital pada materi geometri. Hasil penelitian menyatakan buku digital valid digunakan berdasarkan penilaian ahli media, materi dan guru mata pelajaran. Respon siswa mendapat kriteria sangat layak dan hasil tes siswa berada diatas kriteria ketuntasan minimal yaitu 75. Dengan demikian, buku digital layak dan efektif digunakan untuk meningkatkan hasil belajar siswa serta sebagai sumber belajar mandiri siswa pada materi bangun datar dan bangun ruang.

Penelitian terkait juga dilakukan oleh Fuada, Nainunis, \& Aditya (2017) mengembangkan buku digital materi IPS sejarah. Hasil penelitian menyatakan produk valid digunakan berdasarkan penilaian para ahli dan ujicoba kelompok kecil. Sehingga produk yang dihasilkan layak digunakan setelah memperbaiki produk berdasarkan saran-saran yaitu saran validator, saran pemanfaatan, saran deseminasi dan saran pengembangan.

Penelitian ini berfokus dalam mengembangkan buku digital matematika dengan pendekatan saintifik pada materi persamaan kuadrat. Penelitian ini bertujuan untuk mengembangkan buku digital matematika saintifik untuk persamaan kuadrat yang valid dan praktis.

Produk buku digital matematika saintifik yang dihasilkan berupa softfile produk dalam kepingan compact disk (CD) yang dapat digunakan sebagai sumber belajar mandiri baik secara individu maupun kelompok. Produk buku digital matematika saintifik yang dihasilkan memiliki desain bentuk buku tiga dimensi dengan efek flip pada halaman buku. Selain itu, ditambahkan berbagai bentuk multimedia pendukung pembelajaran seperti gambar, video, fitur tombol, dan lembar kerja peserta didik. Buku digital matematika dapat digunakan untuk pembelajaran luring 
maupun pembelajaran daring, tetapi dengan menggunakan hardware yang telah terinstal aplikasi Flipbook Reader.

Persamaan kuadrat merupakan materi yang didalamnya terdapat sub-materi penting dan saling berkaitan dengan erat, diantaranya mencari akar-akar persamaan kuadrat, mengenal sifat-sifat persamaan kuadrat dan menghitung nilai diskriminan. Dalam mencari akar-akar persamaan kuadrat itu sendiri dapat diselesaikan dengan tiga cara yaitu memfaktorkan, melengkapkan kuadrat sempurna dan menggunakan rumus kuadratik.

\section{METODE PENELITIAN}

Jenis penelitian ini merupakan pengembangan dengan model Analysis, Design, Development, Implementation dan Evaluation (ADDIE). Responden uji coba produk pengembangan adalah siswa kelas 8 dengan jumlah siswa 10 orang di salah satu sekolah SMP di kab. Pinrang. Pemilihan responden uji coba berdasarkan jarak rumah terdekat dari sekolah. Hal ini dikarenakan penelitian dilakukan di masa pandemi.

Teknik pengumpulan data yang digunakan untuk mengembangkan buku digital matematika yaitu observasi, wawancara dan angket. Observasi digunakan untuk mengumpulkan data awal pada tahap pengembangan dan pengaplikasian buku digital matematika. Wawancara digunakan untuk mengetahui masalah yang ada di sekolah. Angket digunakan untuk mengumpulkan informasi atau data dalam penelitian. Instrumen penelitian yang digunakan berupa lembar penilaian media oleh ahli media dan ahli materi untuk mengukur kevalidan, serta angket respon guru dan respon siswa untuk mengukur kepraktisan buku digital matematika.

\section{Analisis Data Kevalidan Buku Digital Matematika}

Data hasil penilaian ahli media dan materi dianalisis menggunakan rumus rata-rata total validitas. Menentukan kategori kevalidan berdasarkan pada tabel 1 .

TABEL 1. Pengkategorian tingkat kevalidan

\begin{tabular}{cl}
\hline Besar & \multicolumn{1}{c}{ Interpretasi } \\
\hline $4,5 \leq R T V \leq 5$ & Sangat Valid \\
$3,5 \leq R T V<4,5$ & Valid \\
$2,5 \leq R T V<3,5$ & Cukup Valid \\
$1,5 \leq R T V<2,5$ & Kurang Valid \\
$0 \leq R T V<1,5$ & Tidak Valid \\
\hline \multicolumn{2}{c}{ Wicaksono, Kusmayadi \& Usodo (2014) }
\end{tabular}

Buku digital matematika dikatakan memenuhi kriteria kevalidan jika kategori tingkat kevalidan dari masing-masing validator adalah valid atau sangat valid.

\section{Analisis Data Kepraktisan Buku Digital Matematika}

Kegiatan yang dilakukan dalam proses analisis data kepraktisan buku digital matematika berdasarkan data respon siswa dan respon guru yaitu data hasil respon dianalisis menggunakan rumus nilai respon. Mencari persentase nilai respon dengan rumus persentase nilai respon. Menentukan kriteria persentase nilai respon per butir pernyataan berdasarkan pada Tabel 2.

Kemudian membuat kategori untuk seluruh butir pernyataan yaitu:

- Jika $\geq 50 \%$ dari seluruh butir pernyataan termasuk dalam kategori sangat kuat atau kuat maka respon siswa dan guru dikatakan positif.

- Jika $<50 \%$ dari seluruh butir pernyataan termasuk dalam kategori sangat kuat atau kuat maka respon siswa dan guru dikatakan negatif. 
TABEL 2. Persentase nilai respon siswa dan guru

\begin{tabular}{lc}
\hline \multicolumn{1}{c}{ Kategori } & Persentase \\
\hline Sangat Lemah & $0 \% \leq N R \leq 20 \%$ \\
Lemah & $20 \% \leq N R<40 \%$ \\
Cukup & $40 \% \leq N R<60 \%$ \\
Kuat & $60 \% \leq N R<80 \%$ \\
Sangat Kuat & $80 \% \leq N R<100 \%$ \\
\hline Wicaksono, dkk (2014) &
\end{tabular}

\section{HASIL DAN PEMBAHASAN}

Penelitian dan pengembangan yang dilakukan ini menghasilkan buku digital matematika yang telah divalidasi dan diujicobakan ke siswa. Selain itu, penelitian ini juga mengembangkan perangkat pendukung dan instrumen-instrumen yang relevan dengan buku digital matematika. Adapun prosedur penelitian dan pengembangan yang dilakukan adalah model ADDIE yang melalui lima tahapan.

\section{Analisis}

Pada tahap ini, dilakukan wawancara bersama guru matematika dan kepala sekolah yang bertujuan untuk mengetahui permasalahan dalam kegiatan pembelajaran dan fasilitas di sekolah. Berdasarkan hasil wawancara dengan guru matematika diperoleh informasi bahwa pembelajaran yang berlangsung hanya menggunakan buku kemendikbud dan memanfaatkan papan tulis serta spidol sebagai media pengantar materi pembelajaran. Guru biasanya hanya menggunakan media yang ditemukan di sekitar. Meskipun guru telah menyusun RPP yang mengacu pada kurikulum 2013 namun pengimplementasiannya tidak sesuai dengan langkah-langkah pembelajaran yang telah dirumuskan. Selain itu, pada kurikulum 2013 menuntut guru agar dapat mempadukan pembelajaran dengan bantuan teknologi. Berdasarkan wawancara dengan kepala sekolah diperoleh informasi bahwa di sekolah tersebut terdapat fasilitas yang memadai yaitu Laboratorium Komputer yang didalamnya terdapat proyektor.

Secara garis besar tahap analisis yaitu tahap analisis kebutuhan siswa disimpulkan bahwa siswa membutuhkan kegiatan pembelajaran yang tidak hanya menggunakan metode ceramah. Sehingga, dibutuhkan bahan ajar atau media pembelajaran yang menarik dan dapat memudahkan siswa dalam mempelajari kembali materi. Pada tahap analisis kurikulum, diketahui bahwa kurikulum yang digunakan adalah kurikulum 2013 yang menggunakan pendekatan saintifik. Pada kurikulum 2013, materi persamaan kuadrat terdiri dari dua kompetensi dasar dan enam tujuan pembelajaran.

\section{Desain}

Buku digital matematika dirancang berdasarkan komponen yang ada dalam buku. Adapun bagian-bagian didalam buku digital matematika yaitu sampul, kata pengantar, deskripsi buku, peta konsep, biografi, uraian materi, latihan soal, lembar kerja peserta didik, lampiran dan profil penulis.

Perangkat yang digunakan yaitu perangkat keras (hardware) dan perangkat lunak (software). Perangkat keras (hardware) berupa Notebook Acer Aspire ES 1. Perangkat lunak (software) berupa Microsoft Word 2010, Blender 2.80, Microsoft PowerPoint 2010, Wondershare Filmora 8.2.2, 3D PageFlip Professional 1.7.7, dan Flipbook Reader. 


\section{Pengembangan}

\section{Pembuatan buku digital}

Langkah awal dalam pembuatan buku digital ini terdiri dari membuat isi buku dan video animasi. Membuat isi buku menggunakan aplikasi Microsoft Word 2010, dimasukkan ke Microsoft PowerPoint 2010 untuk ditambahkan template desain buku dan dimasukkan kedalam aplikasi 3D PageFlip Professional 1.7.7. Membuat video animasi menggunakan Aplikasi Blender 2.80 dan menambahkan instrumental serta efek suara pada video animasi menggunakan Wondershare Filmora 8.2.2. Video animasi yang telah diedit dimasukkan ke dalam aplikasi $3 D$ PageFlip Professional 1.7.7 dan diatur pada posisi yang telah disediakan. Buku digital ini hanya dapat digunakan pada hardware yang telah diinstalkan aplikasi flipbook reader. Berikut merupakan tampilan dari hasil pembuatan buku digital matematika menggunakan 3D PageFlip Professional 1.7.7 yang disajikan dalam gambar 1

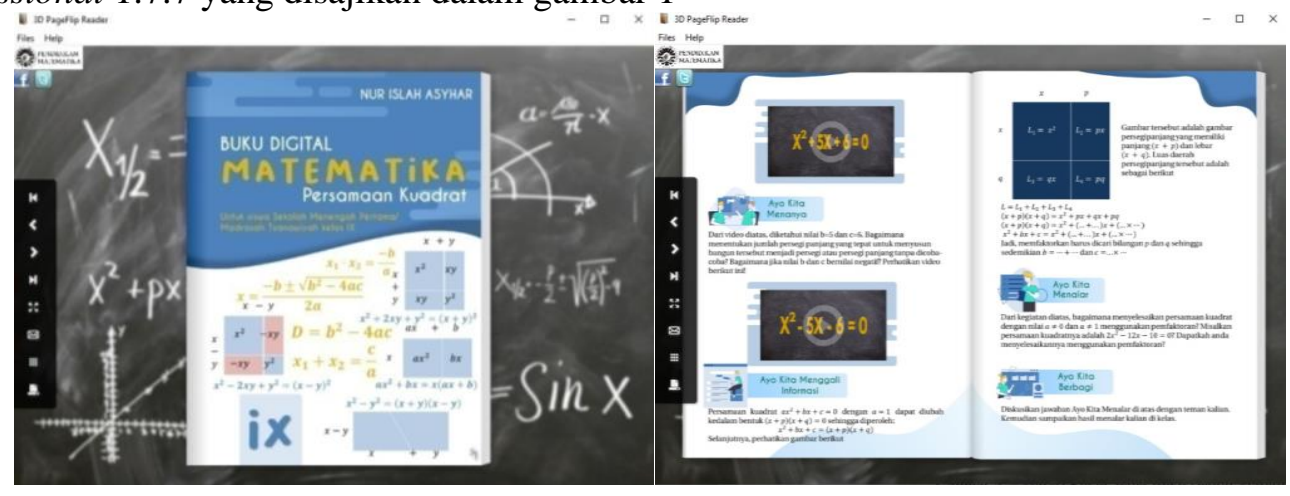

GAMBAR 1. Tampilan Buku Digital Matematika

Validasi dan revisi buku digital

Dilakukan tahap validasi dengan validator yang berkompeten dibidangnya dan dapat memberikan masukan untuk merevisi sehingga buku digital matematika dapat diujicobakan kepada siswa. Berikut merupakan hasil analisis validasi oleh ahli materi.

TABEL 3. Hasil Analisis Validasi Buku Digital Matematika oleh Ahli Materi

\begin{tabular}{lcc}
\hline \multicolumn{1}{c}{ Aspek Penilaian } & Rata-rata Skor & Kategori \\
\hline Aspek Materi & 4 & Valid \\
Aspek Soal & 3,83 & Valid \\
Aspek Kebahasaan & 4 & Valid \\
\hline Rata-rata Total & 3,94 & Valid \\
\hline
\end{tabular}

Berdasarkan tabel 3, nilai tersebut termasuk dalam kategori Valid. Secara umum, kesimpulan penilaian dari validator menyatakan bahwa buku digital matematika yang dikembangkan dapat digunakan dengan revisi.

Berikut merupakan hasil analisis validasi oleh ahli media.

TABEL 4. Hasil Analisis Validasi Buku Digital Matematika oleh Ahli Media

\begin{tabular}{lcc}
\hline \multicolumn{1}{c}{ Aspek Penilaian } & Rata-rata Skor & Kategori \\
\hline Aspek Rekayasa Perangkat Lunak & 4 & Valid \\
Aspek Komunikasi Visual & 4 & Valid \\
\hline Rata-rata Total & 4 & Valid \\
\hline
\end{tabular}

Berdasarkan tabel 4, nilai tersebut termasuk dalam kategori Valid. Secara umum, kesimpulan penilaian dari validator menyatakan bahwa buku digital matematika yang dikembangkan dapat digunakan dengan revisi. 
Berikut revisi terhadap buku digital matematika yang dikembangkan yaitu sebaiknya soal-soal yang berkaitan dengan konteks dalam kehidupan sehari-hari akan menambah lebih variatif dan kontekstual isi dalam buku

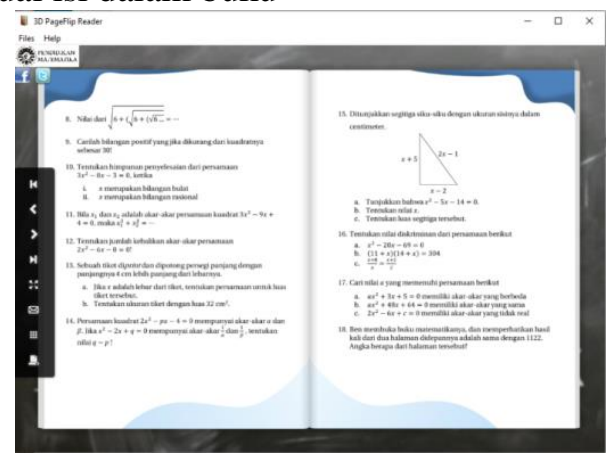

(a)

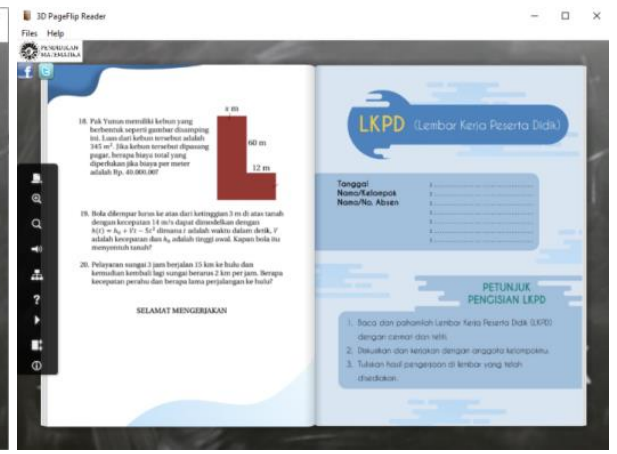

(b)

GAMBAR 2. (a) Sebelum Revisi 1, (b) Setelah Revisi 1

\section{Implementasi}

Buku digital matematika yang telah dikembangkan dan revisi, diujicobakan pada situasi nyata. Tetapi dalam tahap ini, hanya dilakukan uji coba produk terhadap kelompok kecil. Implementasi ini terdiri dari 1 orang guru mata pelajaran dan 10 orang siswa kelas 8. Uji coba produk dilakukan di laboratorium komputer dengan empat kali pertemuan. Pelaksanaan implementasi ini melibatkan satu guru matematika sebagai pengamat. Pengamat bertugas mengamati kemampuan peneliti dalam mengelola pembelajaran serta mengamati aktivitas siswa selama kegiatan pembelajaran berlangsung.

\section{Respon siswa}

Berikut merupakan hasil analisis angket respon siswa.

TABEL 5. Hasil Analisis Angket Respon Siswa

\begin{tabular}{lcc}
\hline \multicolumn{1}{c}{ Aspek Penilaian } & Rata-rata Persentase (\%) & Kategori \\
\hline Aspek Kebahasaan & 81,25 & Sangat Kuat \\
Aspek Materi dan Soal & 80,31 & Sangat Kuat \\
Aspek Kemudahan Penggunaan & 77,50 & Kuat \\
\hline Rata-rata Total & 79,84 & Kuat \\
\hline
\end{tabular}

Berdasarkan tabel 5, nilai tersebut termasuk dalam kategori sangat kuat. Secara umum, dapat disimpulan bahwa respon siswa terhadap buku digital matematika yang dikembangkan adalah positif.

\section{Respon guru}

Berikut merupakan hasil analisis angket respon guru.

TABEL 6. Hasil Analisis Angket Respon Guru

\begin{tabular}{lcc}
\hline \multicolumn{1}{c}{ Aspek Penilaian } & Rata-rata Persentase (\%) & Kategori \\
\hline Aspek Kebahasaan & 87,50 & Sangat Kuat \\
Aspek Materi dan Soal & 88,89 & Sangat Kuat \\
Aspek Kemudahan Penggunaan & 83,33 & Sangat Kuat \\
\hline Rata-rata Total & 87,50 & Sangat Kuat \\
\hline
\end{tabular}


Berdasarkan tabel 6, nilai termasuk dalam kategori sangat kuat. Secara umum, dapat disimpulan bahwa respon guru terhadap buku digital matematika yang dikembangkan adalah positif.

\section{Evaluasi}

Tahap evaluasi dilakukan di setiap tahapan dalam pengembangan. Selain itu, dilakukan revisi akhir terhadap produk yang dikembangkan berdasarkan validitas dan evaluasi kepraktisan. Validitas produk dilakukan oleh ahli media dan ahli materi. Evaluasi kepraktisan berdasarkan hasil angket respon siswa dan guru yang diharapkan buku digital layak digunakan untuk pembelajaran matematika di sekolah.

Nilai rata-rata penilaian ahli materi terhadap buku digital matematika yaitu 3,94. Berdasarkan tabel 1, nilai tersebut berada dalam kategori 3,5 $\leq R T V<4,5$ yaitu valid. Hal ini menunjukkan bahwa materi yang terdapat pada buku digital matematika sesuai dengan kurikulum, aktual, jelas, sistematis dan menggunakan bahasa yang komunikatif. Namun, soal yang terdapat dalam buku digital matematika masih belum sesuai dengan konteks dalam kehidupan sehari-hari.

Nilai rata-rata penilaian ahli media terhadap buku digital matematika yaitu 4. Berdasarkan tabel 1, nilai tersebut berada dalam kategori $3,5 \leq R T V<4,5$ yaitu valid. Hal ini menunjukkan bahwa buku digital matematika yang dikembangkan efektif, efesien, komunikatif dan mudah dioperasikan dalam proses pembelajaran. Selain itu, memiliki tampilan yang menarik baik dari segi visual, teks, audio, video dan gambar.

Buku digital matematika memenuhi kriteria kevalidan baik dari segi materi maupun media. Sehingga buku digital matematika dengan materi persamaan kuadrat dapat dinyatakan layak digunakan dalam proses pembelajaran setelah dilakukan revisi dari masukan dan saran ahli materi dan media.

Persentase nilai rata-rata angket respon siswa yaitu 79,84\%. Berdasarkan tabel 2, persentase nilai berada dalam kategori $60 \% \leq N R<80 \%$ yaitu kuat. Hal ini menunjukkan respon siswa terdapat buku digital matematika yang dikembangkan adalah positif.

Persentase nilai rata-rata angket respon guru yaitu $87,50 \%$. Berdasarkan tabel 2, persentase nilai berada dalam kategori $80 \% \leq N R<100 \%$ yaitu sangat kuat. Hal ini menunjukkan bahwa respon guru terdapat buku digital matematika yang dikembangkan adalah positif.

Buku digital matematika memenuhi kriteria kepraktisan berdasarkan respon positif siswa dan guru. Guru dan siswa mudah dalam menggunakan buku digital matematika dan dapat membantu siswa dengan video animasi untuk mempelajari kembali materi.

\section{KESIMPULAN}

Pengembangan buku digital matematika saintifik pada materi persamaan kuadrat menggunakan model pengembangan ADDIE (Analysis, Design, Development, Implementation dan Evaluation). Buku digital matematika yang dikembangkan termasuk kategori valid dengan nilai rata-rata validasi materi adalah 3,94 dari 5 dan nilai rata-rata validasi media adalah 4 dari 5 . Buku digital matematika dikategorikan praktis digunakan dengan persentase respon guru adalah 87,50\% (respon positif) dan persentase respon siswa adalah 79,84\% (respon positif).

Penelitian pengembangan ini perlu dilakukan pengujian lebih besar agar produk yang dihasilkan lebih teruji dan lebih baik serta pengembangan selanjutnya dapat memuat lebih banyak materi dan dapat digunakan di smartphone. Buku digital ini dapat dijadikan sebagai salah satu sumber belajar siswa, orang tua untuk program homeschooling, sekolah dan lembaga pendidik. Keakuratan tingkat kelayakan produk juga masih dapat ditingkatkan dengan menguji keefektifan produk. 


\section{DAFTAR PUSTAKA}

Andina, E. (2011). Buku Digital dan Pengaturannya. Aspirasi, 2(1). 79-95.

Byun, H. S., Choi, J. I., Song, J. S. (2006). The Research on the Prototype Development of Digital Textbook. Journal of Instructional Technology Research, 22(4). 217-224.

Fuada, S., Nainunis, A. I., Aditya, N, W. (2017). Pengembangan Buku Ajar IPS-Sejarah Digital SMP. Jurnal Teknik Informatika, 10(1). 37-48.

Kim,J.H.Y., \& Jung,H.Y. (2010). South Korean Digital Textbook Project. Computers in the Schools, 27. 247-265.

Marselina, V., Muhtadi, A. (2019). Pengembangan Buku Digital Interaktif Matematika pada Materi Geometri. Jurnal Inovasi Teknologi Pendidikan, 6(2). 196-207.

Prasetya, D. D. (2015). Kesiapan Pembelajaran Berbasis Buku Digital. Jurnal Teknologi Elektro dan Kejuruan, 24(2). 60-64.

Raharjo, H., I'anah. (2014). Pengembangan Bahan Ajar Berbasis Komputer dalam Pembelajaran Matematika Pada Pokok Bahasan Kubus dan Balok. EduMa: Mathematics Education Learning and Teaching, 3(2), 119-132.

Ruddamayanti. (2019). Pemanfaatan Buku Digital dalam Meningkatkan Minat Baca. Prosiding Seminar Nasional Pendidikan Program Pascasarjana Universitas PGRI Palembang (pp. 1193-1202). Palembang, Indonesia: Universitas PGRI Palembang

Sungkono. (2009). Pengembangan dan Pemanfaatan Bahan Ajar Modul dalam Proses Pembelajaran. Majalah Ilmiah Pembelajaran, 1 .

Tambunan, L. R., Sundari, E. (2020). Pengembangan Buku Digital pada Materi Persamaan Garis Singgung Lingkaran. Jurnal Program Studi Pendidikan Matematika, 9(4). 11841191.

Wicaksono, D. P., Kusmayadi, T. A., Usodo, B. (2014). Pengembangan Perangkat Pembelajaran Matematika Berbahasa Inggris Berdasarkan Teori Kecerdasan Majemuk (Multiple Intelligences) pada Materi Balok dan Kubus untuk Kelas VIII SMP. Jurnal Elektronik Pembelajaran Matematika, 2(5). 534-549.

Zaini, H., Darmawan, D., Hernawan, H. (2019). Penggunaan Bahan Ajar Berbasis Digital Book untuk Meningkatkan Hasil Belajar Siswa dalam Mata Pelajaran Matematika pada Materi Logika Matematika (Penelitian Kuasi Eksperimen di Kelas X SMKN 2 Garut). JTEP-Jurnal Teknologi Pendidikan dan Pembelajaran, 4(1), 816-825. 